\title{
Phonological Oppositions of Unstressed Vowels in The Uzbek Language
}

\author{
Radjabov Nasir Nasimovich \\ Associate Professor of the Foreign Language Department of the Public Security University of the \\ Republic of Uzbekistan, Doctor of Philosophy on Philological Sciences, Tashkent, Uzbekistan
}

\begin{abstract}
:
The research deals with the simple classification of phonological oppositions in relation to the unstressed vowels and also, the complex classification of phonological oppositions concerning both the stressed and unstressed vowels in the Uzbek language. The purpose of this study is to explore the extent of forming phonological oppositions of Uzbek vowel phonemes in the unstressed position and to classify the identified phonological oppositions. While carrying out of this study, a comparative method was used to compare vowel phonemes with each other, and a descriptive method was used to express their specific features. In the study, simple and complex classifications of phonological oppositions of Uzbek unstressed vowels have been developed. The study concludes that the phonological oppositions of vowels do not lose their significance in the unstressed positions and according to the simple classification, the unstressed vowels have 9 oppositions whose members are differentiated by one phonological feature, and 6 oppositions whose members are differentiated by two phonological features and according to the complex classification, unidimensional, pluridimensional, proportional, privative, gradual, equipolent and constant oppositions of unstressed vowels exist in modern Uzbek.
\end{abstract}

Key words: unstressed vowels, phonemes, phonological oppositions, distinctive features, unidimensional oppositions, pluridimensional oppositions, proportional oppositions, privative oppositions, gradual oppositions, equipolent oppositions, constant oppositions

\section{Introduction}

Phonology, as a higher stage of phonetics, approaches speech sounds functionally and identifies their distinctive features. Phonologically distinctive features are based on the articulatory-acoustic peculiarities of speech sounds. All the articulatory-acoustic peculiarities of speech sounds are the basis for the phonetic classification of speech sounds whereas some of those peculiarities are selected in the phonological classification. In another word, we can say that the classification of phonemes according to the articulatory-acoustic features is a general method for the phonetic and phonological classifications. If the phonetic classification is based on all the articulatory-acoustic features of speech sounds, the phonological classification selects the main ones from these features, and focusing on their linguistic functions, it identifies their phonologically distinctive peculiarities [1, 59]. Types of phonological opposition are formed on the basis of distinctive features of phonemes and they are classified according to certain criteria. These criteria can be single or united in number. The phonological oppositions divided into small groups on the basis of single criterion can be an example to a simple classification whereas the phonological oppositions based on several criteria is an example to a complex classification. The classification of phonological oppositions proposed by V.A. Vassilyev [7, 183-194] can be considered as a simple classification, for it is based on the single criterion (the criterion of taking into consideration the number of phonological distinctive features in one opposition). And the classification of phonological oppositions suggested by N.S. Trubetskoy 
$[5,73-98]$ can be regarded as a complex one because this classification is based on the several criteria (In this logical classification, oppositions are classified (a) in relation to the entire system of oppositions, (b) according to the relationship between the members of the opposition, (c) on the basis of distinctive force and their occurrence in different positions). The classifications of phonological oppositions proposed by V.A. Vassilyev and N.S. Trubetskoy were first introduced into the Uzbek language by A.A. Abduazizov [2, 41]. In these classifications, the phonological oppositions of vowels as well as consonants were studied. A.Abduazizov made a simple classification of vowel oppositions in the Uzbek language on the basis of the single criterion, that is to say, he used the criterion of taking into consideration the number of phonological distinctive features in one opposition in his classification and mainly focused on stressed positions of vowels. As distinct from the studies mentioned above, in this research we explore the simple classification of phonological oppositions in relation to the unstressed vowels and also, the complex classification of phonological oppositions concerning both the stressed and unstressed vowels in the Uzbek language.

MATERIALS AND METHODS. In Uzbek, vowels are phonetically classified according to the horizontal movement of the tongue, the vertical movement of the tongue and the lip position. But not all of these features can be phonologically distinctive. The phonologically distinctive features of phonemes are determined in agreement with the specific peculiarities of each language. Accordingly, a distinctive feature of phonemes in a particular language may be a non-distinctive feature in another language or vice versa. For instance, the vowel features relating to the horizontal movement of the tongue, and the quantitative peculiarities are not phonologically significant in Uzbek, but in English these features have phonological function and serve to differentiate the lexical meanings of words: /1:/ - /1/ beat /b1:t/ - bit /bit/;/1:/ - /u:/ mean /m1:n/ - moon /mu:n/. And the labial peculiarities of vowels are considered to have phonological value because of being able to differentiate the lexical meanings of words in Uzbek while in English this feature is regarded phonologically insignificant. Besides the labial peculiarities, the vowel features relating to the vertical movement of the tongue have phonological value in Uzbek. The features relating to the horizontal movement of the tongue of Uzbek vowels tend to be changeable depending on the neighboring consonants $[6,34]$, which results in swapping front vowel features for back vowel features or back vowel features for front vowel features under the influence of consonants. It results that this feature of vowels can not serve to differentiate the lexical meaning of words in isolation from the labial feature. The mentioned facts prove that the vowel features relating to the horizontal movement of the tongue is phonologically insignificant for Uzbek vowels.

So, the vowels have two phonologically distinctive features in the Uzbek language. These phonological features are determined by placing vowel phonemes opposite each other in the same positions of words and morphemes. In structural linguistics, the comparison of language units with each other in the same positions is called paradigmatic relations. Analyzing the phonemes in a paradigmatic aspect is the leading method for identifying their distinctive features [1, 59]. Phonological oppositions arise by comparing phonemes in the same places of words and morphemes. H.Jamalkhanov points out that the phonological oppositions are the smallest structural units of the phonological system, which may change their status in the historical evolutions of phonemes. He tries to prove his ideas saying the followings: "For instance, the vowel phonemes in Old Turkic languages had the phonological oppositions based on the features relating to the horizontal movement of the tongue such as /иoppositions have lost their phonological value. As a result of the phoneme convergence, the vowels /и-ы/ were combined into one phoneme $/ \mathbf{и} /$, the vowels $/ \gamma-y /$ were combined into one phoneme $/ \mathbf{y} /$, the vowels $/ \mathrm{e}-\mathrm{o} /$ were combined into one phoneme $/ \mathrm{o} /$, the vowels $/ \mathrm{\partial}-\mathrm{a} /$ were combined into one phoneme /a/. Thus, the phonological oppositions are determined in relation to a certain period of language development and in this period of language development one phoneme is contrasted with 
another in the same position of a word" $[3,94]$. As a result of contrasting phonemes with each other in the same position of a word phonological oppositions are formed. The phonological oppositions of modern Uzbek vowels were firstly studied by A.A. Abduazizov [1, 68] and A.Nurmonov [4, 17]. In these studies, the phonological oppositions of vowels as well as consonants were classified. It should be noted that A.Abduazizov and A.Nurmonov mainly focused on the stressed positions of Uzbek vowels in their classifications. The phonological oppositions may be classified according to one or more criteria. In this regard, two classifications of the phonological oppositions of vowel phonemes can be differentiated in the Uzbek language: a) a simple classification of phonological oppositions, b) a complex classification of phonological oppositions.

RESULTS AND DISCUSSIONS. A simple classification of phonological oppositions. According to the phonetic classification, the phonemes /a, e, 1/ are unrounded, front vowels, and the phonemes /o, ó, $\mathrm{u} /$ are rounded, back vowels in Uzbek. From this classification arises the following phonological oppositions, which are based on one distinctive feature, that is, the feature relating to the lip position: /a-o/, /e-o'/, /1-u/. A.Abduazizov classified the phonological oppositions of Uzbek vowels in the following way according to single criterion (the criterion of taking into consideration the number of phonological distinctive features in one opposition):

a) the phonological oppositions whose members differ from each other by one distinctive feature. In this opposition, the phonemes are distinguished by one of the following features: the vertical movement of the tongue or the lip position: /1-u/, /e-o'/, /a-o/ - unrounded-rounded oppositions; /1-e/, /1-a/, /e-a/, /o'-u/, /o'-o/, /u-o/ - the opposition based on the vertical movement of the tongue;

b) the phonological oppositions based on two distinctive features. The members of these oppositions differ in both the vertical movement of the tongue and the lip position at the same opposition: $/ 1-\mathrm{o}^{\prime} /$, /1-o/, /e-u/, /e-o/, /a-u/, /a-o'/ [1, 68]. However, Uzbek vowels cannot be differentiated by three phonological features. Because the vowel features relating to the horizontal movement of the tongue (front vowel, back vowel) are considered phonologically insignificant in Uzbek as they are changed under the influence of neighbouring consonants. In order to determine if the above-mentioned vowel oppositions change their phonological status depending on the stress, we explored each of those oppositions in stressed and unstressed positions separately and achieved the following results:

Table 1. A simple classification of vowel phonological oppositions

\begin{tabular}{|c|c|c|c|c|}
\hline $\begin{array}{l}\text { Criteria for a } \\
\text { classification }\end{array}$ & $\begin{array}{l}\text { Types of } \\
\text { oppositions }\end{array}$ & $\begin{array}{l}\text { Examples } \\
\text { of } \\
\text { oppositions }\end{array}$ & $\begin{array}{l}\text { Stressed } \\
\text { position }\end{array}$ & Unstressed position \\
\hline $\begin{array}{l}\text { The } \\
\text { phonological } \\
\text { oppositions } \\
\text { whose } \\
\text { members } \\
\text { differ from } \\
\text { each other by } \\
\text { one distinctive } \\
\text { feature: }\end{array}$ & $\begin{array}{l}\text { According to } \\
\text { the horizontal } \\
\text { movement of } \\
\text { the tongue } \\
\text { (closed, } \\
\text { mid-open, } \\
\text { open) }\end{array}$ & $\begin{array}{l}\text { /i-e/ } \\
\text { /i-a/ } \\
/ \mathrm{e}-\mathrm{a} / \\
/ \mathrm{o}^{\prime}-\mathrm{u} / \\
/ \mathrm{o}^{\prime}-\mathrm{o} / \\
\mathrm{u}-\mathrm{o} /\end{array}$ & 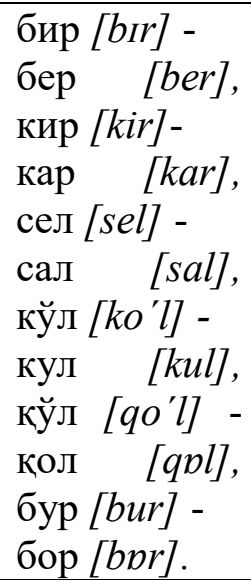 & 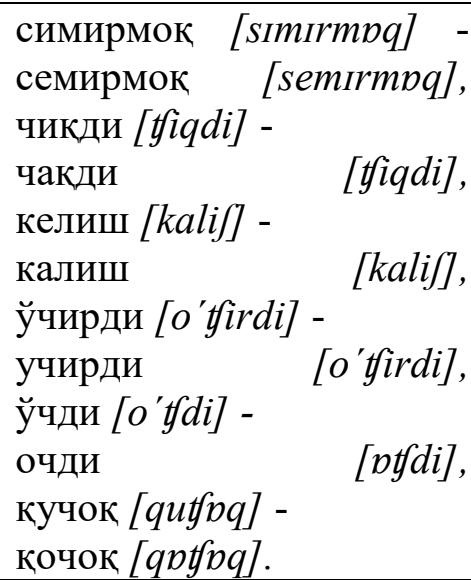 \\
\hline
\end{tabular}




\begin{tabular}{|c|c|c|c|c|}
\hline & $\begin{array}{l}\text { According to } \\
\text { the lip position } \\
\text { (rounded - } \\
\text { unrounded) }\end{array}$ & $\begin{array}{l}/ \mathrm{i}-\mathrm{u} / \\
/ \mathrm{e}-\mathrm{o}^{\prime} / \\
/ \mathrm{a}-\mathrm{o} /\end{array}$ & $\begin{array}{l}\text { қил }[\text { qil] - } \\
\text { қул [qil], } \\
\text { бер }[\text { ber] - } \\
\text { бўр [bo'r], } \\
\text { сал [sal] - } \\
\text { сол [spl]. }\end{array}$ & 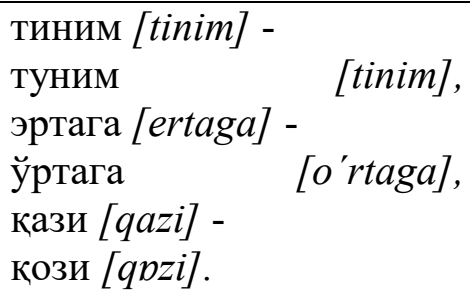 \\
\hline $\begin{array}{l}\text { The } \\
\text { phonological } \\
\text { oppositions } \\
\text { whose } \\
\text { members } \\
\text { differ from } \\
\text { each other by } \\
\text { two distinctive } \\
\text { features: }\end{array}$ & $\begin{array}{l}\text { According to } \\
\text { both the } \\
\text { horizontal } \\
\text { movement of } \\
\text { the tongue and } \\
\text { the lip position } \\
\text { at the same } \\
\text { opposition }\end{array}$ & $\begin{array}{l}/ \mathrm{i}-\mathrm{o} / \\
\text { /i-o/ } \\
\text { /e-u/ } \\
\text { /e-o/ } \\
\text { /a-u/ } \\
\text { /a- o'/ }\end{array}$ & 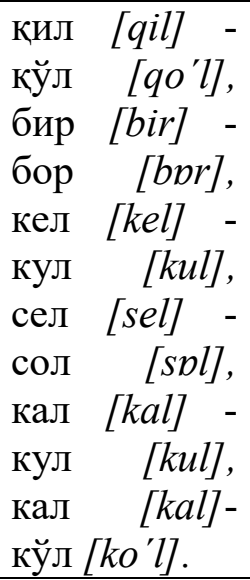 & 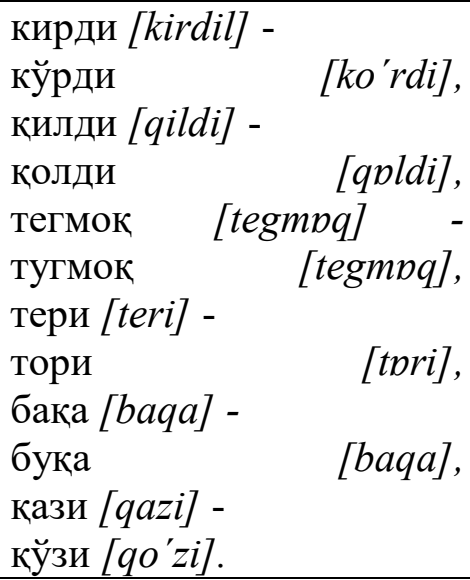 \\
\hline
\end{tabular}

Our research shows that the above mentioned phonological oppositions have the same significance in both the stressed and unstressed positions of vowel phonemes. This means that Uzbek vowels have nine phonological oppositions based on one distinctive feature and six phonological oppositions based on two distinctive features in both the stressed and unstressed positions.

A complex classification of phonological oppositions. The classification proposed by N.S. Trubetskoy [5, 73-98] serves as a basis for developing of a complex classification of the phonological oppositions of vowel phonemes in the Uzbek language. In this logically based classification, oppositions are classified (a) according to the entire system of oppositions, (b) on the basis of the relationship between the members of the opposition, (c) in relation to the distinctive force and their occurrence in different positions.

I. In the classification of phonological oppositions according to the entire system of oppositions unidimensional, pluridimensional, proportional and isolated oppositions are differentiated. If a set of characters belonging to both members of an opposition can not be found in another member of the same system, it is called a unidimensional opposition. The vowel oppositions such as /1-u/, /e-o'/, /ao/ can be examples to the unidimensional oppositions in Uzbek. Because in these oppositions the phonological features belonging to both members of each opposition $\left(/ 1-\mathrm{u} /\right.$ - closed, $/ \mathrm{e}-\mathrm{o}^{\prime} / \mathrm{-}$ midopen, /a-o/ - open) are unique to the members of this opposition and do not occur in any other member of the same system.

If a set of features belonging to both members of an opposition is found in another member of the same system, it is called a pluridimensional opposition. For instance, the labial feature (unrounded) which is common to both members of the vowel opposition /1-e/ occurs in another phoneme in the same system: /a/. Hence, the vowel oppositions /1-e-a/ are considered as pluridimensional

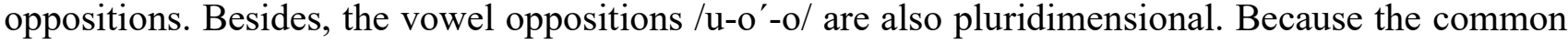
feature belonging to both members of the vowel opposition $/ \mathrm{u}-\mathrm{o}^{\prime} /$ also exists in another phoneme $/ \mathrm{o} /$ in the same system.

If the relationship between the members of one opposition is exactly similar to the relationship between the members of the other opposition in the same system, it is called proportional 
oppositions. For instance, the relationship between the members of the oppositions /1-u/, /e-o'/, /a-o/ (unrounded-rounded) is exactly similar which allows them to be considered as proportional oppositions. On the basis of the distinctive feature "closed-mid-open; unrounded-rounded" the oppositions $/ 1-\mathrm{o}^{\prime} / \mathrm{l} / \mathrm{u}-\mathrm{e} /$; on the basis of the distinctive feature "closed-open; unrounded-rounded" the oppositions /i-o/, /u-a/; on the basis of the distinctive feature "mid-open - open; unroundedrounded" the oppositions /e-o/, / o'-a/ are also examples of proportional oppositions.

If there is not a pair of phonemes which are distinguished on the basis of the distinctive feature of the existing pair of phonemes, such an opposition is called isolated. So, the distinctive feature, which such an opposition is based on, belongs to a single opposition within the whole system. In the Uzbek vowel system, there is not a pair of phonemes which can be an example to this phonological opposition.

The features that are common to both members of the above mentioned unidimensional oppositions (e.g., the feature 'closed' in the opposition /1-u/) can not be found in other oppositions in the same system and seem to be isolated oppositions. However, the vowel feature 'closed' in the opposition /1$\mathrm{u} /$; the vowel feature 'mid-open' in the opposition /e-o'/; and the vowel feature 'open' in the opposition /a-o/ is common to both members of each opposition and cannot be phonologically significant. In an isolated opposition, the relationship between the members should be phonologically distinctive. The isolated opposition is usually characteristic of sonorant consonants, and is manifested in the phonological opposition of /r/ - /1/: тор /tor/ - тол /tol/, кўр /ko'r/ - кўл /ko'1/.

II. In the classification of phonological opposition in relation to their members private, gradual and equipollent oppositions are defined. If the members of the opposition are differentiated from each other by one distinctive feature, such an opposition is regarded as private. The vowel opposition /1-e/ is a privative opposition. Because the vowel feature 'closed' relating to the first member of the opposition does not exist in its second member. Also, the oppositions /u-o'/, /1-a/, /u-o/, /e-a/, /o'-o/ can be examples to a privative opposition because of being based on one distinctive feature.

The phonological oppositions in which it is possible to put other phonemes between their members according to the gradations of their distinctive features are considered to be gradual oppositions. According to the vowel feature relating to the vertical movement of the tongue, the phoneme /e/ (mid-open) can be positioned between the members of the opposition /1-a/ (closed-open), and the phoneme $/ \mathrm{o}^{\prime} /$ (mid-open) can be placed between the members of the opposition /u-o/ (closed-open). Accordingly, the vowel oppositions /1-a/, /u-o/ can be examples to a gradual opposition. Because, in these oppositions, the closed phonemes $/ 1 /, / \mathrm{u} /$ form the phonological oppositions with the open phonemes $/ \mathrm{a} /$ and $/ \mathrm{o} /$ which means the mid-open phonemes $/ \mathrm{e} /$ and $/ \mathrm{o}^{\prime} /$ can be placed between them.

The phonological opposition is called equipollent if the members of opposition have an incidental phonologically non-distinctive character in addition to their main distinctive feature. For example, the vowel oppositions /1-u/, /e-o'/, /a-o/ have one more feature (front - back) which is phonologically insignificant, in addition to their main distinctive feature (unrounded - rounded). Therefore, these vowel oppositions of are equipolent.

III. Oppositions are divided into constant and neutralized ones, according to the distinctive force and their occurrence in different positions. If the members of the opposition do not lose their distinctive features in any phonetic context, it is considered a constant opposition. In the Uzbek language, the private oppositions of vowels such as /1-e/, /u- $\mathrm{o}^{\prime} /, / 1-\mathrm{a} /, / \mathrm{u}-\mathrm{o} /, / \mathrm{e}-\mathrm{a} /, / \mathrm{o}^{\prime}-\mathrm{o} /$, which are based on the vertical movement of the tongue, can be examples to a constant opposition. Because they never lose their distinctive features in any phonetic context. In the unstressed position, the distinctive features of some of these oppositions may change depending on the speaker in the oral style. For example, the second member of the opposition /1-e/ is sometimes pronounced like a semi-long vowel /1/, 
depending on the speaker, in the unstressed position: simirmoq / simirmoq / - semirmoq / $\mathrm{s}(\mathrm{e})$ 1mırmoq /. Besides, the Uzbek vowel $/ \mathrm{o}^{\prime} /$, being a phoneme whose pronunciation is like the sound between the sounds $/ \mathrm{u} /$ and $/ \mathrm{o} /[1,68]$, may be pronounced sometimes like $/ \mathrm{o} /$, and sometimes like $/ \mathrm{u} /$, depending on the speaker. Therefore, the oppositions $/ \mathrm{o}^{\prime}-\mathrm{u} /, / \mathrm{o}^{\prime}-\mathrm{o} / \mathrm{seem}$ to be neutralized. But all of these are the cases which occur in the oral style and are not specific to the literary pronunciation in Uzbek.

If the members of the opposition lose their distinctive features in a particular phonetic context, it is regarded as a neutralized opposition. In the Uzbek language, the equipolent oppositions of vowels such as /1-u/, /e-o'/, /a-o/, having phonologically insignificant feature (front - back) in addition to the main distinctive feature (unrounded-rounded), are similar to the neutralized opposition. It is as if the vowel feature relating to the horizontal movement of the tongue (front - back) is neutralized under the influence of the back and front consonants in such oppositions: /1-u/: қирди /qur'di/ - қурди /qur' $\mathrm{di} /$. In fact, such neutralization is not true. In this case, if neutralization occurs, an archiphonema would be formed on the basis of both members of the phonological opposition /1-u/. However, Uzbek vowels are not neutralized in the unstressed positions. In the mentioned example, a weak qualitative reduction occurs. Phonological neutralization and phonetic reduction differ from each other. Reduction refers to a change in the qualitative or quantitative (long-short) features of a phoneme in the unstressed position (in some languages, for example, in Uzbek, reduction may occur in the stressed position as well). Phonological neutralization, on the other hand, applies to two or more phonemes in the same position. As a result of neutralization, the phonologically distinctive features of the opposition members become similar to each other. For example, if the opposition of long-short vowels is neutralized in some languages, a short-vowel archiphoneme is formed more often, i.e., the long vowel is changed to a short vowel, and the archiphonema chooses one of the long-short vowel features. In the case of the example mentioned above, the archiphoneme gets the vowel feature 'short'.

During the research, it was found that this complex classification of the phonological oppositions of vowels is equally significant for both stressed and unstressed positions. This classification can be expressed in the table as follows:

Table 2. A complex classification of vowel phonological oppositions

\begin{tabular}{|c|c|c|c|c|}
\hline $\begin{array}{l}\text { Criteria for a } \\
\text { classification }\end{array}$ & $\begin{array}{ll}\text { Types } & \text { of } \\
\text { oppositions }\end{array}$ & $\begin{array}{l}\text { Examples } \\
\text { of } \\
\text { oppositions }\end{array}$ & Stressed position & Unstressed position \\
\hline \multirow{2}{*}{$\begin{array}{l}\text { The } \\
\text { classification } \\
\text { of } \\
\text { phonological } \\
\text { oppositions } \\
\text { according to } \\
\text { the entire } \\
\text { system of } \\
\text { oppositions: }\end{array}$} & $\begin{array}{l}\text { Unidimensional } \\
\text { oppositions }\end{array}$ & $\begin{array}{l}\text { /I-U/, } \\
\text { /e-o'/, } \\
\text { /a-p/ }\end{array}$ & $\begin{array}{l}\text { бир [bır] - } \\
\text { бур [bvr]; } \\
\text { кел [kel] - } \\
\text { кўл [ko'l], } \\
\text { хал [hal] - } \\
\text { хол [hol]. }\end{array}$ & 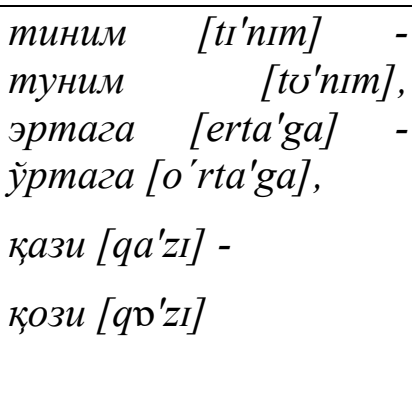 \\
\hline & $\begin{array}{l}\text { Pluridimensional } \\
\text { oppositions }\end{array}$ & $\begin{array}{l}\text { I-e-a/, } \\
/ \mho-o ́-p /\end{array}$ & $\begin{array}{l}\text { кир [kır] - } \\
\text { кер [ker] - } \\
\text { кар [kar], } \\
\text { тур [tor] - }\end{array}$ & 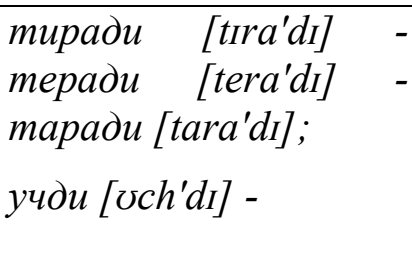 \\
\hline
\end{tabular}




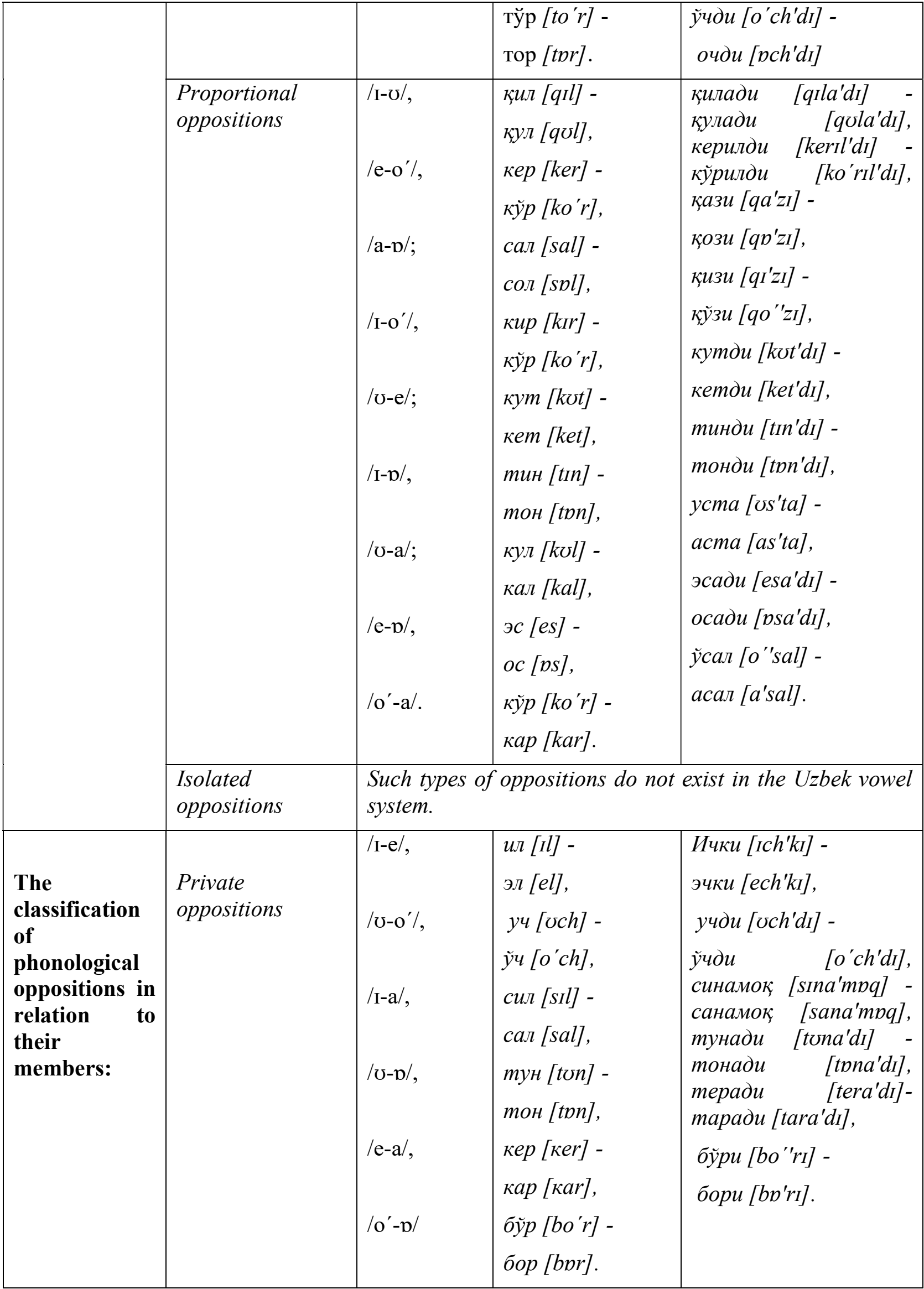




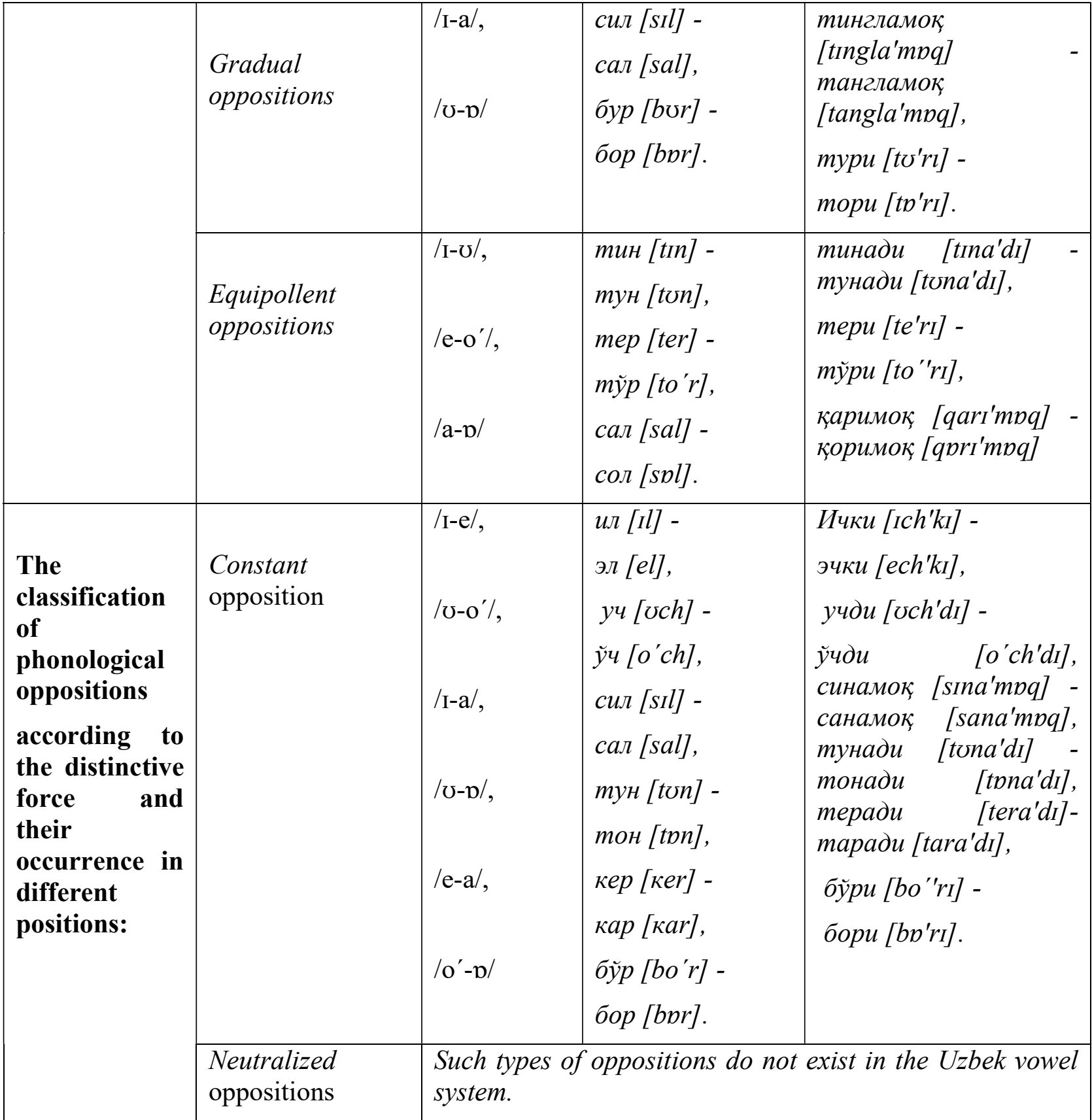

In exploring the types of phonological opposition of vowels according to the stressed or unstressed positions, it is also important to study the distribution of these oppositions in the word. In the process of this research, it has been determined that the phonological oppositions of stressed vowels occur mostly in the initial and middle positions of one syllable words $\left(e . g . / \mho-o^{\prime} /: y u[\mho c h]-\check{y} u\left[o^{\prime} \mathrm{ch}\right] ; \sigma y p\right.$ [bor] - бyрp [bo'r]) whereas in two syllable words these oppositions occur mostly in the postpositions (e.g. /a-i/: тила [tila]-тили [tili]). As to unstressed positions, vowel oppositions occur

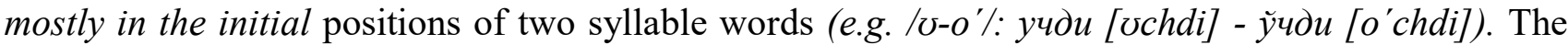
Uzbek language being agglutinative, distribution of vowel oppositions in multisyllable words has its own peculiarities. Occurrence of

stressed vowel oppositions in any positions of the multisyllable words is rare. However, the examples to the phonological oppositions of unstressed vowels can be found in the initial and middle positions of the multisyllable words, for instance, ишладилар [ifladilar] - ушладилар [эfladilar]; 
эшиклар [еfiklar] - эшаклар [efaklar]. It should be noted that the phonological oppositions of unstressed vowels may occur in both open and closed syllables in the initial position of a word consisting two or more syllables: /i-e/: симирмоқ [simir'moq] - семирмоқ [sетіr'тоq], кирмоқ [kir'moq] - кермоқ [ker'moq], /i-a/: иритмоқ [irit'moq] - аритмоқ [arit'moq], чиқмоқ [tiq'moq] чақммоқ [taq'moq].

CONCLUSION. The phonological oppositions of vowels may function in both stressed and unstressed positions in the Uzbek language. The features relating to the vertical movement of the tongue and the lip position are phonologically relevant for Uzbek vowels. The phonological oppositions of vowels based on these distinctive features do not lose their significance even in the unstressed positions. The unstressed vowels, like stressed ones, have 9 oppositions whose members are differentiated by one phonological feature (by the feature relating to either the horizontal movement of the tongue, or the lip position), and 6 oppositions whose members are differentiated by two phonological features (both of the horizontal movement of the tongue and the lip position being relevant in the same opposition).

Phonological oppositions are the smallest structural unit of a phonological system. Because of being possible to be historically changed, the phonological oppositions are identified depending on a particular stage of language development. Accordingly, the following types of phonological oppositions of unstressed vowels are differentiated in modern Uzbek: unidimensional, pluridimensional, proportional, privative, gradual and equipolent oppositions. But there is not an isolated oppositions in the vowel system of the Uzbek language. The privative oppositions of unstressed vowels are constant (priority), and equipolent oppositions are syntagmatically changeable in the literary pronunciation of this language.

Phonological oppositions of vowels may occur in the initial, middle (in one syllable words) and post (in two syllable words) positions in the stressed syllables whereas they mainly occur in the initial and middle positions of two or multisyllable words in the unstressed positions. The stress being mainly in the last syllable, the phonological opposition of unstressed vowels is almost non-existent in the post position of two or multisyllable words in Uzbek. Hence, the phonological opposition of vowels is more common in the initial part of a word in both stressed and unstressed positions. Existence of such oppositions in the middle position of a word is much less common in the stressed positions than in the unstressed ones. These phonological oppositions may occur in the post positions of a word mostly in the stressed positions.

\section{REFERENCE:}

1. Абдуазизов А. Ўзбек тили фонологияси ва морфонологияси. 2-нашр. - Т.: Ўқитувчи, 2010. -172 б.

2. Баскаков Н.А., Содиқов А.С., Абдуазизов А.А. Умумий тилшунослик. - Т.: Ўқитувчи, 1979. - 191 б.

3. Жамолхонов Х. Ўзбек тилининг назарий фонетикаси. - Т.: Фан, 2009. - 222 б.

4. Нурмонов А. Ўзбек тили фонологияси ва морфонологияси. - Т.: Ўқитувчи, 1990. - 46 б.

5. Трубецкой Н.С. Основы фонологии. 2-го изд. - Москва: Аспект Пресс, 2000. - 352 с.

6. Турсунов У., Мухторов А., Рахматуллаев Ш. Хозирги ўзбек адабий тили. - Т.: Ўзбекистон, 1992. - 120 б.

7. Vassilyev V.A. English Phonetics (A Theoretical Course). - Moscow: High School Publ. House, 1970. $-324 \mathrm{p}$. 